\title{
RATING BANKS IN EMERGING MARKETS: What Credit Rating Agencies Should Learn From Financial Indicators
}

\author{
Liliana Rojas-Suarez \\ Visiting Fellow \\ Institute for International Economics
}

\begin{abstract}
The rating agencies' and bank supervisors' records of prompt identification of banking problems in emerging markets has not been satisfactory. This paper suggests that such deficiencies could be explained by the use of financial indicators that, while appropriate for industrial countries, do not work in emerging markets. Among the conclusions, this paper shows that the most commonly used indicator of banking problems in industrial countries, the capital-to-asset ratio, has performed poorly as an indicator of banking problems in Latin America and East Asia. This is because of (a) severe deficiencies in the accounting and regulatory framework and (b) lack of liquid markets for bank shares, subordinated debt and other bank liabilities and assets needed to validate the "real" worth of a bank as opposed to its accounting value.

In spite of these problems, an appropriate set of indicators for banking problems in emerging markets can be constructed. But such a system should be based not on the quality of banks loans or on levels of capitalization, but on the general principle that good indicators of banking problems are those that reveal the "true" riskiness of individual banks because they are based on markets that work rather than just relying on accounting figures. Of the alternative indicators proposed in this paper, interest rate paid on deposits and interest rate spreads have proven to be strong performers. In contrast to the interpretation of banks' spreads in industrial countries, low spreads in emerging markets have not always indicated an increased in bank efficiency. Instead, low spreads have often reflected the high-risk taking behavior of weak banks.

A difficulty that rating agencies may encounter in considering the suggested approach in this paper is that the methodology implies that the appropriate indicators of banks' performance evolve over time as markets develop and that, given large differences among emerging markets, a single set of indicators will not "fit all". The basic principle that "indicators work where markets work" is the leading guide to the selection of effective indicators. In spite of these considerations, we believe that in facing the trade-off between "uniformity across countries" and "effective indicators", rating agencies would be better off by focusing on the latter.
\end{abstract}

This paper has greatly benefited from the comments, suggestions and research assistant support from Yira Mascaro (who contributed to an earlier version of this paper) and Maritza Rojas.

The author also would like to thank comments by participants in seminars 
at New York University and the Brookings Institution. Financial support from

The Center for International Political Economy is greatly acknowledged.

\section{INTRODUCTION}

How should the strength of banks be best assessed? Answering this question is at the core of the business of two very different economic agents: policymakers and credit rating agencies. While the policymakers' main objective is to minimize the costs associated with existing financial-markets safety nets, the objective of rating agencies is to provide investors with an adequate measurement of the risks involved in instruments issued by the financial institutions they rate.

Although objectives differ significantly between banking supervisors and rating agencies, the mechanics to assess bank soundness are not so different. The major difference lies in the supervisory capacity to conduct on-site inspections at will and, most important, in the policymakers' right to impose sanctions on financial institutions that misreport required information. However, a crucial similarity between these two kinds of institutions is that both base their evaluation of bank strength on sets of financial and economic indicators that tend to be quite alike. For example, the capitalization ratio is a core statistic used by both bank supervisory authorities and credit rating agencies. Moreover, if the recent Basel G-10 Committee's proposal for a new capital adequacy framework (or a modified version) is eventually implemented, there will be an important interconnection between the activities of private credit rating agencies and banks' supervisory authorities. 1

In this context, it is clear that both sets of institutions could benefit from each other's improvements in methodologies to identify and assess bank risk.

Benefits from improvements in assessing banks' financial risks are the greatest in emerging markets, where evidence shows that the costs of banking crises in terms of lost economic growth are higher than in industrial countries, and problems in a single bank have a high probability of turning into a systemic crisis. Indeed, in contrast with industrial countries, it is difficult to find episodes in emerging

\footnotetext{
${ }^{1}$ A major motivation behind the reform proposal of the Basel Committee for a new capital adequacy framework-the most recent manifestation of international efforts to improve the incentive structure for banks' allocation of risk-is the recognition that the present risk-weighting system used in the computation of minimum capital requirements distorts banks' incentives for risk-taking activities. In that context, appropriate capitalization, under the current Basel Accord, does not necessarily provide the best indication of bank soundness. While the new Basel proposal is currently in its last stage of review, one of the most contentious issues has been the replacement of the present riskweighting system with the use of credit assessment for determining risk weights. In the new Basel proposal, credit assessment involves the use of banks' own internal ratings and/or the use of external ratings as provided by independent rating agencies. See BIS (2001) for the latest version of the proposed New Basel Capital Accord and, Fitch IBCA (2000) for representative comments by rating agencies on this proposal.

${ }^{2}$ For a comparison of the resolution costs of banking crises between Latin American and industrial countries, see Rojas-
} 
markets where the failure of an important bank has not been accompanied by a systemic crisis. Yet, in spite of these considerations, the success record of both, domestic supervisory authorities and credit rating agencies, in anticipating severe banking difficulties in emerging markets remains very disappointing.

What are the most common indicators used by policymakers and rating agencies in assessing banks' performance in emerging markets? These can be divided in two categories: (a) the macroeconomic environment (including the political, legal, and judicial landscape) and (b) microeconomic factors as represented by bank-specific financial ratios.

However, in spite of the wide recognition that both macroeconomic and microeconomic factors are behind the eruption of severe banking problems in emerging markets, most of the research literature on this subject focuses largely on identifying changes in macroeconomic variables that predict systemic banking

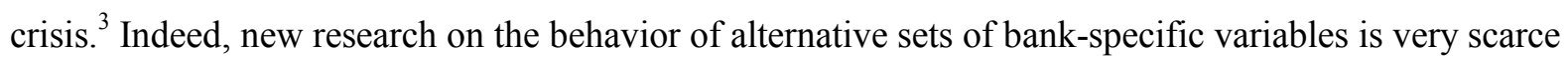
and, to a large extent, is confined to straightforward applications of the financial indicators of bank soundness used in industrial countries. ${ }^{4}$ This is in sharp contrast with a vast literature on industrial countries, which seeks to identify changes in bank-specific variables that lead to bank difficulties 5

Consider the following statement from a Moody's report: “...when rating emerging-market banks as opposed to those in developed markets...financial statistics and ratios are less valuable as a way of measuring bank strength and of comparing banks with each other...[instead] the economy and environment in which the banks operate is a much more important driver of financial strength".

Thus, when policymakers, analysts, and rating agencies assess bank soundness, an asymmetry emerges: while there is a perceived need to identify the particular set of macroeconomic variables that affect banks' performance in emerging markets, it is also assumed that the set of financial bank ratios used to evaluate banks in industrial countries is the appropriate one for emerging markets.

While this approach is not surprising and largely responds to the large and highly volatile

Suarez and Weisbrod (1996). For a discussion of the costs of banking crises in a large number of developing countries, see Caprio and Klingebiel (1996), Lindgren et al. (1996) and Honohan and Klingebiel (2000). For an analysis of the costs associated with the recent Asian crisis, see Lindgren et al. (1999).

3 At the macro level, the most comprehensive analysis of early warning indicators of systemic banking crisis can be found in Goldstein, Kaminsky, and Reinhart (2000). See also, Kaminsky and Reinhart (1999), and Dermiguc-Kunt and Detragiache (2000).

${ }^{4}$ Exceptions are Gonzalez-Hermosillo et al. (1996), who include bank-specific variables as leading indicators of banking crises in Mexico. In addition, Honohan (1997) proposes a list of early-warning indicators for banking problems in developing and transition economies that includes both macroeconomic and bank-specific variables. More recently, Bongini et al (1999) assess the predictability power of CAMEL-type variables on banking failures in East Asia.

${ }^{5}$ See, among others, Sinkey (1975), Martin (1977), Sharpe (1978), Barth et al. (1985), Benston (1985) and Whelen and Thomson (1988). For a review of this literature, see Demirguc-Kunt (1989).

${ }^{6}$ See Moody's (1999). 
macroeconomic imbalances that characterize emerging markets relative to industrial countries, hypothesis in this paper is that it is equally important to identify the "right" set of bank-specific indicators that convey adequate information of financial strength in emerging markets. Should rating agencies and policymakers be content to use bank financial ratios similar to those developed in industrial countries? Based on the analysis of recent episodes of banking crises in Latin America and East Asia, this paper shows that such a set of indicators may prove ineffective in detecting banking problems in emerging markets. The paper also shows, however, that when certain limitations now facing emerging economies are taken into account, an efficient set of alternative indicators can be constructed and used by rating agencies. Needless to say, the proposed set of alternative indicators can also be used as part of an early warning system to be used by supervisory authorities in emerging markets.

The rest of the paper is organized as follows: Section II explores the pre-conditions behind the effectiveness of traditional bank ratios used in industrial countries and argues that emerging markets lack such pre-conditions. Section III proposes an alternative set of indicators of bank strength that works for emerging markets now, when the preconditions needed for effective implementation of industrial country standards are not yet in place. Section IV tests such a system by applying it to six recent banking crises in emerging markets: three in Latin America (Mexico 1994-95, Venezuela 1994, and Colombia 1982-86) and three in East Asia (Korea, Thailand, and Malaysia; all of which erupted in 1997). Section V concludes the paper.

\section{TRADITIONAL BANK RATIOS: WHAT CONSTRAINS THEIR EFFECTIVENESS IN EMERGING MARKETS?}

To a large extent, credit rating agencies use similar indicators of bank strength as those used by bank regulators in industrial countries. As discussed above, in addition to assessing the overall macrosupervisory-legal environment in which banks operate ("the operating environment" in Moody's

\footnotetext{
${ }^{7}$ The emphasis on a "macro-approach" responds to a number of features that distinguish emerging markets from their industrialized counterparts. First, large and adverse macroeconomic shocks have threatened domestic banks on two fronts: by depleting the sources of bank funding and/or by impairing the quality of bank assets. For example, shocks to fiscal accounts may create expectations of inflation or devaluation, which result in severe contraction of bank deposits, thus reducing banks' liquidity. Moreover, since in a number of emerging markets, corporations are highly indebted in short-term US dollar-loans, large exchange rate depreciations tend to deteriorate the creditworthiness of firms whose revenues are denominated in the domestic currency (largely, the nontradable sector). This, in turn, adversely affects the quality of banks' loan portfolios, even if the banks themselves followed prudential recommendations about maximum uncovered foreign exchange positions. The impact of these shocks tends to be much larger in emerging markets than in industrial countries because the financial system in the former is shallower than the financial system in the latter; implying that long-term loans denominated in domestic currencies are practically nonexistent in emerging markets. Second, not only the mean but also the variance of certain key macroeconomic variables is much larger in emerging markets, indicating that financial institutions in this region operate in a riskier environment.
} 
terminology or the "market environment and planning" in Fitch IBCA's terms), rating agencies use a relatively compact set of financial indicators derived from banks' balance sheets and income statements (Moody's calls them "financial fundamentals"). Indicators of bank strength can be summarized in five key variables. Together, these variables--capital adequacy, asset quality, management, earnings, and liquidity-are called the CAMEL system (or a variation of it), a system widely used by bank supervisors in industrial countries. Capital adequacy, asset quality, and liquidity are the three most important indicators. In the case of banking supervisors, reports by the US Treasury indicate that this system has functioned relatively well. That capital adequacy - the "core" ratio used by banking supervisors - is also a key financial indicator used by credit rating agencies in emerging markets is stressed in the following statement by Moody's: "The strength of capital and provisions is a more important element in the analysis of emerging market banks than is the case with banks in developed markets."

In addition to the CAMEL variables, researchers have argued for using market-based indicators of banking difficulties such as the price of bank equity (Pettway and Sinkey, 1980, and Sherman, 1980) or subordinated debt (Flannery and Sorescu, 1996). When available, rating agencies use this indicator as well.

A number of financial experts have noted, however, that the underpricing of deposit insurance reduces the usefulness of markets in pricing equity. This is so because when governments provide deposit insurance, the government is a de-facto contributor of capital to a bank. As a result, there is an increased incentive for risk-taking activities at the expense of the official safety net. Therefore, some analysts suggest that, to assess the true value of a bank's equity, one should subtract an estimate of the capitalized value of any government guarantees from the market value of equity.

To take into account the fact that a country-specific safety net may imply the survival of a bank even if such an institution faces severe financial difficulties, rating agencies provide two sets of ratings. The first set measures a bank's standalone strength, that is, the capacity of a bank to meet its obligations without external support (the "Bank Financial Strength Rating" in Moody's case or the "Bank Individual Rating" in Fitch IBCA's case). The second set measures whether a bank would receive support should this be necessary to repay its obligations (the "Debt/Deposit Rating" in Moody's case, the "Support Rating" in Fitch IBCA's case). Can traditional bank ratios and market-based indicators be effective indicators of bank strength in industrial countries? This paper argues that traditional indicators work where two sets of conditions are met. The first set relates to the quality of data and the supervisory framework, and the second to the existence and efficiency of markets. Regarding the former, it is well recognized that traditional bank ratios such as the capital-to-risk-weighted asset ratio are useless indicators of bank strength 
when accounting standards and reporting systems are inappropriate, nonperforming loans are classified inadequately, and reserves against credit losses are underprovisioned. In addition, a deficient legal

framework, unable to enforce supervisory actions when a bank's performance is deemed faulty, seriously undermines the effectiveness of bank ratios.

But even when accounting, reporting, and legal frameworks are adequate, bank ratios will be less effective if liquid markets for bank shares, subordinated debt, and other bank liabilities and assets are not available to validate the "real" value of bank capital as distinct from its accounting value. For example, changes in the market value of bank capital provide information to supervisors and rating agencies regarding the quality of reported capital.

Neither set of conditions is fulfilled in emerging markets. Regarding the first set of conditions, although serious efforts are under way to deal with reporting and accounting problems, deficiencies in the legal system remain a major obstacle. But even if regulatory and legal systems were improved, and relatively quickly, certain more fundamental characteristics of the environment in which financial markets operate prevent the second set of conditions from being met in the short run. In particular, the high concentration of ownership of assets, both financial and real, and the resulting lack of liquid capital markets, are a major hindrance to the effectiveness of industrial-country banking ratios in emerging markets.

Again the capital-to-risk-weighted asset ratio shows why this is so. The purpose of setting minimum capital standards is to increase the proportion of uninsured funding (equity and subordinated debt) to insured funding (deposits), and so reduce bank stockholders' incentive to take risks at the expense of the public safety net. But when wealth is highly concentrated, as it is in many emerging markets, the intent of the capital standard can be easily subverted, even when supervision is on a consolidated basis. Supervisors and rating agencies alike have difficulty determining whether shareholders' wealth is really at risk when they supply equity capital to a bank, because shareholders can finance their stake with a loan from a related party (which may be a nonfinancial corporation, and hence outside the regulators' purview). Thus, concentration of wealth encourages investors to supply low-quality bank capital. The public safety net will then be severely underpriced, creating greater incentives for bank risk taking than prevail in industrial countries, where developed capital markets assess the quality of capital supplied to banks (RojasSuarez and Weisbrod, 1997).

\footnotetext{
${ }^{8}$ See Moody's (1999).

${ }^{9}$ This issue is, of course, well recognized by rating agencies. Indeed, part of the argument to give more weight to macroeconomic variables lies in the recognition of the "quality" problems of bank-specific variables.
} 
All this suggests that it is relatively easy for bank owners in emerging markets to raise large amounts of low-quality capital relative to the bank's capital base in a short time. Indeed, as figure 1 shows, real growth rates of capital, net of reevaluation adjustments to bank assets and retained earnings, have been quite high (sometimes exceeding 30 percent) in a number of emerging markets: (Argentina (ARG), Colombia (COL), Ecuador (ECU), Indonesia (IND), Malaysia (MAL), Mexico (MEX), Thailand (THA), and Peru (PER) in recent years. That capital standards have not constrained the expansion of risky assets is demonstrated by the fact that net real equity growth was extremely high in years when a banking crisis was in the making. This is the case in Mexico 1993, Argentina 1993, Ecuador 1995, Indonesia, Malaysia, and Thailand in 1995-96. 10 In contrast, growth rates of capital in real terms in the industrialized countries displayed in figure 1, United States (USA), Japan (JAP), Norway (NOR), and Sweden (SWE), have remained less than 10 percent. Indeed, a feature of figure 1 is that emerging markets are grouped in the upper right side of the figure while industrial countries are all concentrated in the lower left side.

It could be argued that the high rates of growth of real capital in emerging markets are the result of an alternative explanation: rapid growth rates in real terms could be attributed to the fact that bank capital in these countries starts from a very low base relative to large industrial countries and, therefore, that the data indicate a stock adjustment problem rather than the low quality of the market for bank stock. It is to deal with this issue that figure 1 includes two small industrialized countries, namely, Norway and Sweden. These Scandinavian countries experienced banking crises in the early 1990s. In none of these two cases, however, on the eve of their banking crises (1991), bank net equity in real terms experienced rates of expansion of the magnitude observed in emerging markets. Indeed, the rate of growth of net equity behaved as it is expected for industrial countries: in the presence of problems in the banking system, net equity growth became negative in real terms. These observations indicate that the low quality of bank capital is a problem associated with the degree of financial development rather than with the size of the economy.

\footnotetext{
${ }^{10}$ Although the Mexican banking crisis fully erupted in 1994, recent analysis has demonstrated that such a crisis originated in the rapid expansion of risky loans during 1993. See, for example, Rojas-Suarez and Weisbrod (1995).
} 
Figure 1 Real loan growth and real net equity growth in select banking systems

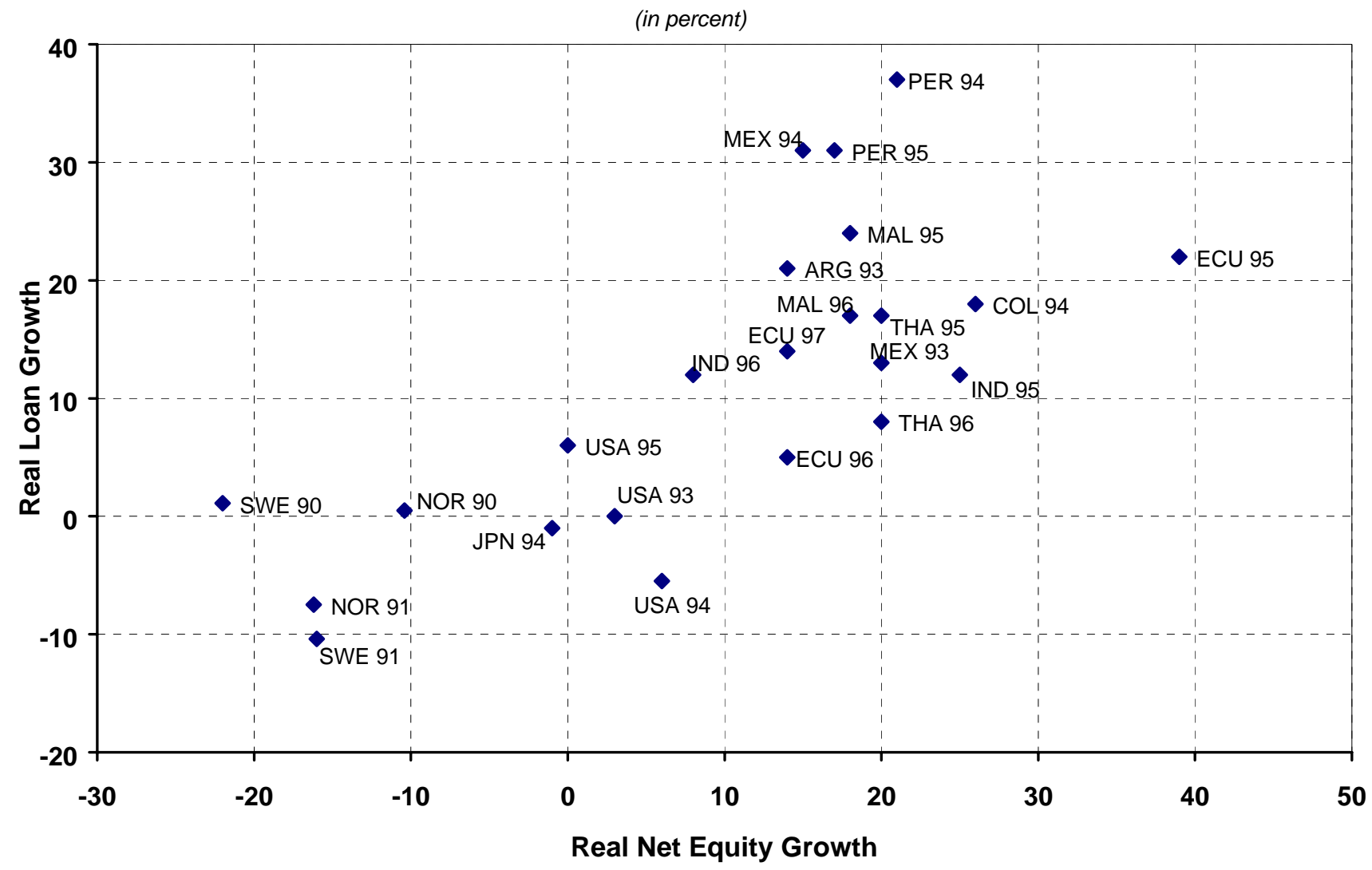

Source: Rojas-Suarez and Weisbrod (1997), various Central Banks statistics and IFS data.

In addition, it is important to stress that the small capital base that characterizes developing countries is precisely the reason why major wealth holders are able to control most banks in a given country and that the drastic changes in the rate of growth of capital is a further indication of the capacity of stockholders to mobilize capital quickly and easily. 


\section{CAN AN ALTERNATIVE SET OF INDICATORS OF BANK STRENGTH BE DESIGNED FOR EMERGING MARKETS?}

In the context of the discussion above, it is not surprising that policymakers, rating agencies and the market at large have missed the eruption of severe banking difficulties in emerging markets. They have, bluntly put, focused on the wrong indicators. What, then, can rating agencies do to better detect surfacing problems (or performance improvements) in banks, until the regulatory and supervisory environment can be improved and until capital markets mature? One solution is to design an alternative set of financial indicators that takes the distinguishing features of these economies into account. Such a system should be based not on the quality of bank loans or on levels of bank capitalization, but on the general principle that good indicators of banking problems are those that reveal the "true" riskiness of bank activities. Such a system can provide an effective complement to macroeconomic indicators aimed at detecting systemwide fragilities.

The rest of this section takes the specific features of emerging markets into account to identify bank-specific indicators that can work in this region.

The first step in the identification of appropriate financial indicators of bank strength in emerging markets is to recognize the significant process of financial liberalization that many of these countries have undertaken during the last decade. While the degree of financial liberalization has varied widely across countries, in many emerging markets, interest rates on bank deposits and loans are now totally unrestricted. Targeted credit programs have also been dismantled in many countries, although the extension of liberalization in this area in greater in some regions (i.e., Latin America) than in others (i.e., East Asia). In addition, to make the banking industry more competitive, new banks have been allowed to enter. However, rules and regulations allowing new entry have generally not been accompanied by strict and promptly enforced exit rules for banks whose performance is found inadequate. For example, a tradition of regulatory forbearance for nonviable financial institutions in East Asia is widely cited as a major cause of the recent financial crises in the region. 1 As already discussed, the distinguishing features of emerging financial markets imply that many financial institutions are not adequately capitalized, as supervisors are unable to assess the real market value of capital. Together with a lack of political will to close failing banks, this failing in many countries has induced poorly managed banks to attempt to increase their market share by rapidly expanding their loan portfolio through loans to risky borrowers. ${ }^{2}$ Funding for these loans has been obtained, at least in part, by offering high deposit rates. The resulting increases in funding costs

\footnotetext{
${ }^{11}$ See, for example, Lindgren et al. (1999).

${ }^{12}$ As discussed in the previous section, capital standards have not been effective in controlling the expansion of banks' balances sheets of risky institutions.
} 
have not been translated into proportional increases in loan rates, as banks are aware that this could cause their risky borrowers to default. Consequently, spreads between deposit and lending rates at risky institutions have remained low or have even declined during periods of excessive risk taking.

At least three indicators, all of them based on "peer" comparisons with other banks, can provide effective indicators of the degree of risk taking activities of banks: rapid growth in the loan portfolio relative to other banks; deposit rates significantly above those offered by other banks; and deposit-lending rate spreads significantly below the system average. Note that narrow spreads should be interpreted differently in emerging financial markets than in industrial-country financial markets. In the latter, narrow spreads often reflect efficiency in the provision of financial services, but as the next section will show, narrow spreads in the emerging markets context can indicate increased bank risk taking.

Another useful indicator, namely, access of banks to funds from the interbank market, is also market based. Often those best informed about a bank's financial condition are other banks. When sound banks perceive that a bank is taking undue risk, they react by reducing that bank's access to interbank funding. This indicator, however, only is useful in cases where a well-established and liquid interbank market exists.

\section{TESTING THE EFFECTIVENESS OF ALTERNATIVE BANK INDICATORS}

Do the alternative indicators proposed here provide more information about the strength of a bank in emerging markets than those commonly used in industrial countries? This section examines the usefulness of these alternative indicators using bank-specific data for the recent banking crises in six emerging markets: three in Latin America, namely, Mexico, Venezuela, and Colombia, and three in East Asia, namely, Thailand, Korea, and Malaysia.

The starting point to test such a set of indicators is to keep in mind that, as in the case of CAMEL, an effective set of proposed indicators of bank strength, that could be useful for rating agencies, should also form the basis for an early warning system used by banking supervisors. As such, a way to test whether a proposed set of indicators is effective is to examine empirically whether they could perform as

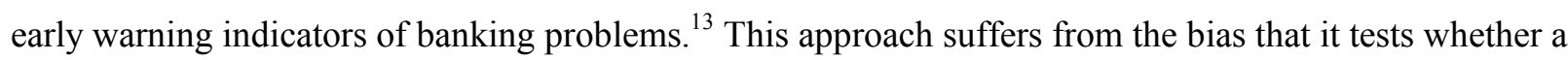
bank's performance is weakening and not whether it is improving. That is, the tests performed in this section could provide a signal for a bank's "downgrade" by a rating agency. However, the intent of this paper is not to suggest a precise methodology that rating agencies could use. Instead, it has the more

\footnotetext{
${ }^{13}$ Another version of this paper, "Early Warning Indicators of Banking Crises: What Works for Emerging Markets" focuses on the need for banking regulatory and supervisory authorities to focus on alternative set of indicators to those used in industrial countries.
} 
modest purpose of presenting alternative indicators of bank strength that we believe would allow to improve the rating performance of the agencies. If the proposed indicators work as "early warning signals", they should certainly need to be considered by rating agencies.

The empirical analysis in this section aims at comparing the appropriateness of the alternative indicators relative to the traditional ones by using a two-step approach. The first step consists in determining whether each indicator of the two competing sets behaved significantly differently in banks that experienced a crisis relative to the variables' behavior in the noncrisis banks. The presumption here is that the fact that not all banks failed during a crisis episode is an indication that the banks that survived the crisis behaved differently before the eruption of the crisis than the banks that failed. Marcus' (1984) analysis of banks' response to financial deregulation serves as the basis for this presumption. Marcus concluded that after financial markets are liberalized, banks tend to gravitate toward either a high-risk or low-risk posture. When an adverse shock occurs, the high-risk banks have a larger possibility of failure. Therefore, the key to construct an appropriate set of indicators that can alert for changes in banks' performance is to identify those variables that best characterize the differences in banks' behavior toward risk. Before a crisis such variables should behave differently in crisis-prone banks than in the low-risk banks. To test whether such difference in behavior effectively occurred in the cases under consideration, we test whether the mean of the variables included in the two alternative set of indicators differed significantly between banks that failed and banks that survived. To do this, we used t-tests for the difference in the means and the Mann-Whitney test for the difference in the medians of the two groups of banks. It is important to note that variance analysis determined that some indicators had similar variance for the two groups of banks while the variance differed significantly for other indicators. T-tests were conducted accordingly (t-test equal variance or t-test unequal variance)

The second step to assess the appropriateness of the alternative set of indicators proposed in this paper uses the "signal approach" popularized for the study of exchange rate crises by Kaminsky and Reinhart (1999). Here an indicator that exceeds a specified threshold provides a "signal" that should alert rating agencies, analysts, and supervisors to a weakening of bank performance. An indicator is considered "good" when it emits a signal that is followed (within 12 months) by problems in the bank in question, or when no signal is emitted and no problems follow. Likewise, an indicator is considered "bad" when its emission of a signal is not followed by bank problems, or when no signal was issued and problems do follow.

The exercise was conducted for two alternative definitions of banking crises; the results presented here are those for the case where crisis is defined as actual intervention by the authorities, either to close the bank, to recapitalize it using public resources, or to provide strong liquidity support. The alternative 
definition of crisis not presented here is defined as a period when the ratio of nonperforming loans to total loans is greater than the average for the system as a whole during a tranquil period plus two standard deviations. Results for the alternative definition generally did not differ significantly from those presented in this paper.

Table 1 presents the traditional and alternative indicators considered. 14 The table also specifies the thresholds used in the second step. With the exception of the interest rate variables, capitalization, change in equity prices and growth of interbank debt, the definition of the thresholds for the rest of the variables followed two alternative approaches. The first compares the behavior of a bank-specific variable relative to the average of the total banking system in the period under analysis. In this alternative, a variable was said to provide a signal when it diverged from the system average by one standard deviation. The second approach compares the behavior of a bank-specific variable relative to the behavior of that variable in a tranquil period; that is, in a period when no significant bank failures occurred. A variable was said to provide a signal when its value diverged from the tranquil period by more than one standard deviation. The reason to conduct the exercise under the two alternative definitions of thresholds was to deal with some issues associated with systemic banking crisis. Specifically, it could be argued that in episodes when a large number of banks failed, the usefulness of "peer" comparison with other banks within the same period could be reduced. However, the empirical investigation indicated that the results of the analysis did not change significantly by using the alternative definitions of thresholds.

Thresholds for changes in equity prices and growth of interbank debt were defined to reflect a drastic change in the period before the crisis. When quarterly data was available, as in the case of Mexico, the threshold required that the change persisted for at least two quarters. It is important to note that, because of the limited development of capital markets in the countries under consideration, analysis of equity prices was restricted to the sample of banks that actively traded in the domestic stock exchanges.

Thresholds for the capitalization ratio also depended on data availability. When data on riskweighted-capital-to-asset ratios were available (Mexico), the threshold was set at 8 percent in accordance with the Basel standards; that is, risk-weighted-capital-to-asset ratios less than 8 percent were taken as providing a signal of banking problems. In countries where such data were not available (Venezuela, Colombia, and the three East Asian countries in our sample) the threshold specified a drastic decline in the unweighted capital ratio.

\footnotetext{
${ }^{14}$ The ratio of nonperforming loans to loans is not included in the traditional system because changes in that variable are
} 


\section{Latin America}

The results of the analysis for the three Latin American countries are presented in tables 2 and 3. A discussion of these results on a country-by-country basis follows.

\section{Mexico}

The banking crisis in Mexico that fully erupted by the end of 1994, affected a large proportion of banks in the system. The Mexican sample analyzed in this paper is formed by 19 domestic commercial banks during the period 1992-95. All bank-specific data is quarterly and is from the Banking Supervisory Commission.

Table 2 presents the results from the first step of the analysis. At first sight, with the exception of change in equity prices, all the other variables appear as potential candidates to be part of a set of indicators that would allow to distinguish among banks according to performance since either the mean or the median (or both in a number of cases) of problem banks differed significantly from the corresponding statistics of noncrisis banks. A closer look, however, reveals the ineffectiveness of most traditional indicators. For example, both groups of banks appeared to be well-capitalized, with risk-weighted capitalto-asset ratios above the minimum 8 percent recommended by the Basel Committee. This standard did not provide rating agencies with an effective tool to assess the quality of individual banks. Moreover, contrary to the predictions of the traditional bank ratios used in industrial countries, liquidity ratios of problem banks were higher than the noncrisis banks and cost ratios of problem banks were lower than the corresponding mean and median for noncrisis banks. The only indicator in the traditional system that worked in the expected direction is the ratio of net profits to income.

In contrast to the performance of most traditional indicators, all the indicators in the alternative system performed as predicted. Signaling an increase in risk-taking activities, banks that ended in crisis offered, on average, higher deposits rates and lower interest rate spreads than banks that remained solvent. In addition, problem banks expanded loans significantly more rapid than solvent banks and had less access to funding from the interbank market.

Turning to the second step of the analysis, the application of the signal approach to the crisis periods in Mexico, yields the results presented in table 3. The first column indicates what percentage of problem banks was accurately predicted by the indicators. The second column shows the ratio of "good" to "bad" signals as defined above. A ratio greater than one implies that the indicator issued a "good" signal more than 50 percent of the times.

used to construct one of the two alternative definitions of banking crisis. 
As it has become customary in analysis of bank failures, a type I error can be defined as the case when a variable issues no signal of crisis for a bank that will end in crisis. A type II error is produced when a variable issues a signal of crisis for a strong bank. Low numbers for a variable in the first column indicate a high type I error rate as the indicator "missed" a significant number of problem banks.

As reported in the literature (see, for example Sinkey [1979] and Lane et al [1986]), in assessing the quality of banking crises indicators, type I errors are more important than type II errors. If having to choose between indicators, most bank analysts would prefer an indicator with a low type I error rate, even if that variable experienced a high type II error rate, over an indicator with a high type I error rate, even if that variable experienced a low type II error rate. This is because the analysts perceive that the costs associated with missing problem banks is higher than the costs associated with misclassifying strong banks as weak

The main result from this exercise when applied to Mexico is that, taken as a whole, the alternative early warning indicators provided better signals of bank difficulties than the traditional indicators, confirming the results obtained in the first step. Of the traditional ratios, the capital-to-asset ratio and the liquidity ratio, the ones that are the most popular in industrial countries, performed the worst as predictors of banking problems in Mexico. Data in the first column of table 3 are indicative of the high rate of type I error experienced by these two variables. As in the analysis of means and medians, the ratio of net profits to income was the best performer among traditional indicators.

As predicted by the hypothesis raised in this paper, the best-performing indicators were those based on information provided by the market: interest rates paid on deposits, interest rate spreads and interbank lending. In contrast to what is observed in industrial countries, but in accordance with our hypothesis, narrow bank spreads were good indicators of banking problems in Mexico since they reflected the high risk-taking behavior of weak banks.

\section{Venezuela}

As in the case of Mexico, the banking crisis in Venezuela that emerged in 1994 affected a large number of banks in the system. Out of the 35 banks included in the sample, 13 were either closed or taken over by the authorities. These 13 banks accounted for about half of total banking system deposits at the eve of the crisis. All the data is from the Central Bank of Venezuela. In contrast to Mexico, however, bank-specific quarterly data is not available for the relevant period and the analysis is restricted to the information reported by banks every six months (June and December). 
Results from the first step of the analysis (table 2) indicate that, although there are many similarities with the Mexican case, some of the results are not as clear-cut as in Mexico and need to be interpreted in conjunction with the results for Venezuela in table 3.

Among the traditional indicators, lack of data prevented the inclusion of changes in equity prices. Not only a small proportion of banks were listed in the stock exchange, but also fewer traded frequently. Lack of liquidity in this market supports the hypothesis that change in bank equity prices is not an appropriate early indicator of bank performance. With respect to the rest of traditional indicators, although the mean and/or median of all of these indicators differed significantly between the two groups of banks, the results for the liquidity ratios and the ratio of operating costs to assets were contrary to the prediction of the traditional set of indicators: banks in problems reported higher liquidity ratios and lower ratios of operating costs than solvent banks. Most important, as shown in table 3, all of the traditional indicators have a very low performance rate in predicting bank problems. As discussed above, this signals a very high type I error rate.

In contrast, the interest rate on deposits was the best indicator of banking problems not only among alternative indicators but also on an overall basis. Not only did it have a high degree of accuracy in predicting banks that will end in crisis (a low Type I error), but it also showed the highest ratio of good to bad signals of all the indicators. As predicted by the hypothesis raised in this paper, efforts of high-risk banks to raise funds led to high deposit rates offered by this type of banks.

Results from table 3 also show that bank interest-rate-spread was a better performer than the traditional ones as crisis banks showed, on average, a lower spread than noncrisis banks. This variable also presented a low type I error rate, supporting the hypothesis of this paper.

Table 2 indicates that the interbank debt ratio may not be an appropriate early-warning indicator as there is no significant difference in the mean and/or median between failing and nonfailing banks. Although the results from table 3 indicate that this variable performs relatively well in predicting banking problems, its very low ratio of good to bad signals reinforces the results from table 2 . As in the case of stock prices, the inappropriateness of this indicator may be due to the lack of a well-developed and liquid interbank market in Venezuela.

Although less strongly than in the Mexican case, the overall results for the Venezuelan case support the conclusion that an appropriate assessment of the performance of Latin American banks needs to be based on indicators associated with markets that work. Consistent with this principle, deposit rates and interest rate spreads are the two indicators that performed the best among all indicators considered in this paper. 


\section{Colombia}

The banking crisis in Colombia analyzed here was significantly different from those in Mexico and Venezuela. First, it started in the early 1980s when financial market liberalization and competition among banks was not a feature of Latin America. Second, although the crisis affected a significant proportion of banks in the system, it spread over time. Indeed, in contrast to Mexico and Venezuela, where the largest effects of the crises concentrated in a couple of years, the crisis in Colombia started in 1982 and continued throughout 1987. The sample considered in this study includes 18 commercial banks, out of which 7 experienced severe difficulties. Data availability is on a semi-annual basis. The data is from the Central Bank of Colombia and the Banking Superintendency.

In section III it was argued that the best criteria to identify appropriate indicators of banks performance was to focus on banking variables where the workings of markets validated the accounting figures provided by banks. In applying this general principle to the Colombian banking crisis, it is important to take into account the major features that characterized the Colombian financial markets during the period under consideration. The two most important characteristics for our purposes are: first, although interest rates on deposits and loans were not fixed, the Central Bank offered banks attractive fixed discount rates on loans extended by banks to certain areas defined as "priority areas" by the government. In doing so, the authorities effectively guaranteed banks a spread on loans made to firms in priority areas. Second, and related to the first feature, competition for entry into the banking system was practically nonexistent. With the government guaranteeing banks a certain spread on certain types of loans, competition for funds in the deposit market was not necessary. In this context, two of the indicators proposed in the alternative system, interest rates on deposits and interest rate spreads, are irrelevant in the Colombian case. However, riskiness of the loan portfolio net of loans protected by the government may be reflected in the overall loan rate. Hence, that variable was included among the alternative set of indicators. As in the Venezuelan case, lack of liquidity in the interbank market also prevented to use that variable in the set of alternative indicators.

Given the greater restrictions to the functioning of markets in the Colombian banking crisis of the 1980s relative to that of the crises in Mexico and Venezuela in the 1990s, the possible alternative indicators for an effective early-warning system was very limited in Colombia. Notwithstanding these limitations, the Colombian case is included in this paper to test the general principle that better signals of bank problems should be obtained from variables that reflect market behavior, even if markets are not fully free to operate.

In spite of all the limitations of this case, results from tables 2 and 3 are consistent with the results obtained for the cases of Mexico and Venezuela. Once again, on an overall basis, the market indicator, 
interest rate on loans, was the best performer among all indicators. It presented the highest rate of accuracy in predicting bank problems (a low type I error) and the highest ratio of good to bad signals. Also on an overall basis, the rate of growth of loans performed better than all of the traditional indicators. As in the cases of Mexico and Venezuela, the most commonly used traditional indicators, the capital-to-asset ratio and the liquidity ratio were not good performers. As shown in table 3, these two indicators showed a high type I error rate. Moreover, as shown in table 2, the behavior of the capital-to-asset ratio was contrary to the expectations of the traditional system: on average, banks that ended in crisis had significantly higher capital ratios than solvent banks. The mean and median analysis also showed that the liquidity ratio was not a useful indicator of problems in banks.

\section{East Asia}

Results for the analysis conducted on three East Asian countries are presented in tables 4 and 5. In contrast to the Latin American cases, where each crisis occurred in a different period of time and were not generally interrelated, the three crises cases in Asia erupted during the period 1997-98. The specific-bank data for the Asian countries came from a common database that compiled data from balance sheets of individual banks. While the advantage of a common database is that comparison across countries are easier to undertake, there are also important shortcomings. For the purpose of our analysis, we identified three limitations: first, the data is compiled on an annual basis, restricting our capacity to understand the signaling capacity of an indicator. For example, we could not determine whether an indicator provided a signal early in the year and kept signaling or whether it temporarily gave a signal that did not continue during the year. Second, the data is presented in such a way that we were not able to clearly identify the variable "interbank debt". As such, we lost an important variable in our set of "alternative" indicators. Third, data on equity prices was also not available.

\section{Thailand}

Problems in the financial system erupted in Thailand in early 1997. Out of the 15 domestic commercial banks operating at the end of 1996, 11 faced severe difficulties and required support from the government.

The results from the first step of the analysis show that none of the traditional indicators qualify to belong in a system aiming at distinguishing among banks according to quality. This is so because neither the mean nor the median of problem banks differed significantly from those of noncrisis banks.

The statistical results in Thailand show large similarities with those obtained for Mexico. First, as in Mexico, the capital-to-assets ratio proved totally ineffective as a mechanism to identify problem banks. Indeed, weaker banks in Thailand showed a higher ratio than the stronger banks on the eve of the crisis. 
Second, also as in the Mexican case, liquidity ratios of problem banks were either higher than or nondifferentiable from those in strong banks, rendering this indicator useless for both rating agencies and supervisors. Third, average cost ratios of problem banks were lower than those in noncrisis banks in both countries. Fourth, among the traditional indicators, the ratio of net profits to income was the only one that worked in the expected fashion. Fifth, the alternative indicators, interest rate on deposits and bank spreads, performed as predicted by the hypothesis in this paper: weaker banks offered higher deposit rates and lower interest rate spreads than banks that remained strong after the crisis. The only important difference with Mexico was that problem banks in Thailand expanded loans at practically the same rate than solvent banks.

The second step of the analysis confirmed the results obtained in the first step. The traditional indicators had a low rate of success in predicting crises, the capital-to-assets ratio being the worst. In the same fashion, the traditional indicators displayed a low ratio of good to bad signals, an indication of the high rate of type I error experienced by these variables. Consistent with the analysis of means and medians, the profitability ratio was the relatively best performer among traditional indicators.

In contrast, and similar to the Mexican results, the best performers on an overall basis, were the interest rate on deposits and the interest rate spread. These two variables not only produced the highest accuracy in predicting bank problems, but also produced the lowest level of "noise", that is, ratios of good to bad signals greater than one. While the rate of growth of loans also showed a low rate of type I error, it only called a crisis correctly 50 percent of the times. This, of course, is consistent with the first step of the analysis that demonstrates that the rate of expansion of loans by weak Thailand banks was quite similar to that of stronger institutions.

\section{Korea}

As in the case of Thailand, the banking crisis in Korea included a large proportion of domestic institutions. Out of the 26 Korean commercial banks existing at the end of 1996, 16 were affected by the crisis either through closure, mergers, or recapitalization programs supported by public funds. As a result of large injections of government capital, the government ended up owing shares in the majority of remaining banks, which in some cases reached 90 percent of total shares.

To understand the performance of the traditional indicators in Korea, the analysis from means and medians cannot be separated from the "signals" analysis. Consider for example the capitalization variable. As predicted by the traditional approach, banks that ended in crisis held lower capital ratios than stronger banks. The t-test, however, indicated that the difference in means between the two groups of banks was not significant. Moreover, as shown in table 5, the capitalization ratio was a meaningless variable to 
distinguish between banks according to quality. This ratio always gave a signal; that is, all banks (strong and weak) experienced a sharp reduction in their capital to asset ratio on the eve of the crisis, rendering the indicator a useless tool to distinguish between strong and weak banks. In other words, this indicator produced an extremely large amount of "noise." While we have argued that minimizing type I error is more important than avoiding type II error, the capitalization ratio in Korea displayed a nonacceptable high rate of type II error: it issued a signal of crisis for all banks that remained strong.

Results for the rest of traditional indicators were mixed. The performance of the cost ratio was poor. Contrary to the predictions of the traditional approach, this indicator showed that crisis banks experienced, on average, a lower cost ratio than stronger banks. Consistent with this finding, the cost ratio was only capable to accurately predict 20 percent of the crisis cases and displayed a high rate of type I error.

Among the traditional variables, the best results were obtained by the liquidity ratio and the net profits to income ratio. As predicted by the traditional approach, weaker banks held lower liquidity and profitability ratios. These two indicators had a decent performance: while the liquidity ratio accurately predicted 56 percent of crisis episodes, the profitability ratio predicted 60 percent of such episodes.

On an overall basis, however, two of the "alternative" indicators, interest rate on deposits and bank spreads were the best performers. As stated in the hypothesis in this paper, weaker banks revealed their higher preference for risk-taking activities by offering higher deposit rates and lower spreads than stronger banks. The capacity of these two indicators to accurately predict a crisis was also impressive; the deposit rate variable accurately predicted 80 percent of the crisis episodes and the spread variable correctly called 90 percent of the crisis cases. Furthermore, with ratios of "good to bad" signal significantly above 1, these ratios displayed a strong capacity to avoid error type I.

As in the case of Thailand, the rate of growth of loans did not perform well as weak and strong banks expanded their loan portfolio in undistinguishable fashion. All results taken together seem to indicate that the markets discriminated among banks through prices (interest rates) rather than quantities. Weak banks were able to expand their lending activities but at the expense of paying higher deposit rates to depositors.

\section{Malaysia}

While still quite severe, the banking crisis in Malaysia affected a relatively lower number of institutions than in Thailand and Korea. Out of 22 domestic commercial banks in existence in 1996, 8 received strong government support. 
In contrast to Thailand and Korea, in Malaysia neither set of indicators can be declared a clear winner. Malaysia being the least liberalized financial system in the sample, market indicators did not perform as well as in the other two Asian cases. While, on an overall basis, bank spreads was the best indicator since it correctly predicted 88 percent of the crisis with a high ratio of good to bad signals, interest rate on deposits paid by stronger banks could not be significantly distinguished from the rates paid by weaker banks. Also, as in Korea and Thailand, both weak and strong banks were able to expand credit rapidly.

In the context of a less liberalized financial system, the traditional indicators did not perform well either. For example, while weaker banks held lesser capital than stronger banks, the capital-to-asset ratio accurately predicted only 37 percent of the cases that ended in crisis and displayed a low capacity to avoid type I error. Neither the profitability ratio nor the cost ratio was useful indicators since the behavior of these two variables was similar for strong and weak banks. Moreover, their predicting capacity was very low, correctly calling only 50 percent and 25 percent of the crisis situations, respectively. Relatively speaking, the liquidity ratio was the best performer among traditional variables since it showed that banks in crisis held less liquidity, on average, than noncrisis banks. However, the predictive "quality" of this variable was very low as it displayed a high rate of type I error.

The results for Malaysia are consistent with our basic premise that an indicator works only when supported by the market. It is, therefore, not surprising that in a less liberalized financial system, market indicators become less useful as tools for assessing the quality of banks.

\section{CONCLUDING REMARKS}

Credit rating agencies in the business of rating banks claim as one of their main functions the assessment of a bank's financial strength as measured by its capacity to meet its obligations (without the support of government bailouts) and its effectiveness to manage risk. To a large extent, these functions are shared by domestic banking supervisors and, therefore, there is a common interest in identifying the best indicators of banks' financial performance.

The rating agencies record of prompt identification of banking problems in emerging markets has not been satisfactory, and neither has been that of banking supervisors. This paper suggests that such deficiencies could be explained by the use of financial indicators that, while appropriate for industrial countries, do not work in emerging markets. Indeed, the results from the empirical analysis conducted in this paper support the view that the particular features of financial markets in emerging markets limit the effectiveness of traditional indicators of bank performance and that an alternative system needs to be in 
place at least in the short-run, while these countries improve their legal and regulatory framework and capital markets develop.

The paper showed that the most commonly used indicator of banking problems in industrial countries, the capital-to-asset ratio has performed poorly as an indicator of banking problems in Latin America and East Asia. This is because of two reasons: first, because of severe deficiencies in the accounting and regulatory framework, the meaning of traditional ratios is extremely limited. Second, bank ratios become less effective when liquid markets for bank shares, subordinated debt and other bank liabilities and assets are not available to validate the "real" worth of a bank as opposed to its accounting value.

In spite of these problems, an appropriate set of indicators for banking problems in emerging markets can be constructed. But such a system should be based not on the quality of banks loans or on levels of capitalization, but on the general principle that good indicators of banking problems are those that reveal the "true" riskiness of individual banks because they are based on markets that work rather than just relying on accounting figures. Of the alternative indicators proposed in this paper, interest rate paid on deposits and interest rate spreads have proven to be strong performers by showing a high degree of accuracy in predicting banking problems. In contrast to the interpretation of bank spreads in industrial countries, low spreads in emerging markets have not always indicated increased bank efficiency. Instead, low spreads have often reflected the high risk-taking behavior of weak banks.

Difficulties that rating agencies may encounter in considering the suggested approach in this paper are twofold: first, the methodology implies that the appropriate indicators of banks' performance evolve over time as markets develop. Second, because emerging markets differ significantly among themselves in their degree of financial depth and development, a single set of indicators will not "fit all". The basic principle that "indicators work where markets work" is the leading guide to the selection of effective indicators.

In spite of these considerations, we believe that in facing the trade-off between "uniformity across countries" and "effective indicators", rating agencies would be better off by focusing on the latter. 


\section{Table 1 Traditional and alternative indicators of bank strength}

\section{Traditional Indicators}

\begin{tabular}{|c|c|}
\hline Indicator & Thresholds: Indicator gives a signal if \\
\hline Capitalization & $\begin{array}{l}\text { (a) Less than } 8 \text { percent for at least } 2 \text { consecutive quarters } \\
\text { (for risk-weighted-capital-to-asset ratio) } \\
\text { (b) Decline of more than } 10 \text { percent persisting for at least } \\
\text { two consecutive quarters (for capital-to-asset ratio and } \\
\text { equity-to-asset ratio). }\end{array}$ \\
\hline Equity prices & $\begin{array}{l}\text { (a) Decline of more than } 10 \text { percent persisting for at least } \\
\text { two consecutive quarters. }\end{array}$ \\
\hline Ratio of net profits to total income ${ }^{1}$ & $\begin{array}{l}\text { (a) Below banking system mean, evaluated for the entire } \\
\text { period, by } 1 \text { standard deviation. } \\
\text { (b) Below banking system mean, evaluated for the tranquil } \\
\text { period, by } 1 \text { standard deviation. }\end{array}$ \\
\hline Ratio of operating costs to total assets ${ }^{1}$ & $\begin{array}{l}\text { (a) Above banking system mean, evaluated for the entire } \\
\text { period, by } 1 \text { standard deviation. } \\
\text { (b) Above banking system mean, evaluated for the tranquil } \\
\text { period, by } 1 \text { standard deviation. }\end{array}$ \\
\hline Liquid assets to total deposits & $\begin{array}{l}\text { (a) Below banking system mean, evaluated for the entire } \\
\text { period, by } 1 \text { standard deviation. } \\
\text { (b) Below banking system mean, evaluated for the tranquil } \\
\text { period, by } 1 \text { standard deviation. }\end{array}$ \\
\hline
\end{tabular}

\section{Alternative Indicators}

\begin{tabular}{|l|l|}
\hline Indicator & Thresholds: Indicator gives a signal if: \\
\hline Implicit interest rate paid on deposits & $\begin{array}{l}\text { (a) Greater than system mean (calculated separately for each } \\
\text { period) plus 1 standard deviation. }\end{array}$ \\
Rate of loan growth & $\begin{array}{l}\text { (a) Less than system mean (calculated separately for each } \\
\text { period) plus 1 standard deviation. }\end{array}$ \\
Growth of interbank debt & $\begin{array}{l}\text { (a) Above banking system mean, evaluated for the entire } \\
\text { period, by 1 standard deviation. } \\
\text { (b) Above banking system mean, evaluated for the tranquil } \\
\text { period, by 1 standard deviation. }\end{array}$ \\
\hline $\begin{array}{l}\text { 1. Estimated as the ratio of bank's interest payments to total deposits. } \\
\text { 2. Spread = (ratio of interest received to total loans) - (ratio of interest payments to total deposits) }\end{array}$ \\
\hline
\end{tabular}


Table 2 Means and medians of traditional and alternative early warning indicators in Mexico (1993-95), Venezuela (1993-94), and Colombia (1981-1988) ${ }^{\text {a, b }}$

\begin{tabular}{|c|c|c|c|c|c|c|c|c|c|c|c|c|}
\hline Countries & \multicolumn{4}{|c|}{ MEXICO } & \multicolumn{4}{|c|}{ VENEZUELA } & \multicolumn{4}{|c|}{ COLOMBIA } \\
\hline & \multicolumn{2}{|c|}{ Means } & \multicolumn{2}{|c|}{ Medians } & \multicolumn{2}{|c|}{ Means } & \multicolumn{2}{|c|}{ Medians } & \multicolumn{2}{|c|}{ Means } & \multicolumn{2}{|c|}{ Medians } \\
\hline & $\begin{array}{l}\text { Banks } \\
\text { in crisis }\end{array}$ & $\begin{array}{l}\text { Noncrisis } \\
\text { banks }\end{array}$ & $\begin{array}{l}\text { Banks in } \\
\text { crisis }\end{array}$ & $\begin{array}{l}\text { Noncrisis } \\
\text { banks }\end{array}$ & $\begin{array}{l}\text { Banks } \\
\text { in crisis }\end{array}$ & $\begin{array}{l}\text { Noncrisis } \\
\text { banks }\end{array}$ & $\begin{array}{l}\text { Banks } \\
\text { in crisis }\end{array}$ & $\begin{array}{l}\text { Noncrisis } \\
\text { banks }\end{array}$ & $\begin{array}{l}\text { Banks } \\
\text { in crisis }\end{array}$ & $\begin{array}{l}\text { Noncrisis } \\
\text { banks }\end{array}$ & $\begin{array}{l}\text { Banks } \\
\text { in crisis }\end{array}$ & $\begin{array}{l}\text { Noncrisis } \\
\text { banks }\end{array}$ \\
\hline Traditional indicators & & & & & & & & & & & & \\
\hline Capitalization $^{\mathrm{c}}$ & $9.38 * * *$ & 10.49 & $8.90 * *$ & 10.27 & $3.47 * * *$ & 5.15 & $2.21 *$ & 4.65 & $4.66 * * *$ & 2.14 & $2.09 * * *$ & 1.68 \\
\hline Change in equity prices & -2.27 & -2.2 & -0.41 & 0.22 & n.a. & n.a. & n.a. & n.a. & $-6.92 * *$ & 2.93 & $-3.57 * *$ & 0.07 \\
\hline Net profits to income & $2.93 * * *$ & 5.75 & $4.50 * * *$ & 5.98 & $4.59 * *$ & 12.06 & $3.70 * * *$ & 9.02 & $-7.32 * * *$ & 5.16 & $1.62 * * *$ & 5.24 \\
\hline Operating costs to assets & $1.10 * * *$ & 1.29 & $1.07 * * *$ & 1.26 & $4.64 * * *$ & 5.03 & $4.16 * * *$ & 4.78 & $6.21 * * *$ & 4.81 & $4.57 * * *$ & 4.07 \\
\hline Liquidity ratio & $6.34 * * *$ & 4.78 & 4.92 & 4.09 & $48.39 * *$ & 43.29 & 45.60 & 39.76 & 34.59 & 34.70 & 32.79 & 35.13 \\
\hline Alternative indicators & & & & & & & & & & & & \\
\hline Interest rate on deposits ${ }^{\mathrm{d}}$ & 6.32 & 5.67 & 4.79* & 4.37 & 26.58 & 23.89 & $25.84 *$ & 20.45 & $3.37 * *$ & 3.69 & 3.28 & 3.81 \\
\hline Bank spread & $5.69 * * *$ & 9.24 & $5.62 * * *$ & 8.49 & $19.87 *$ & 23.27 & $27.55 * *$ & 18.10 & n.a. & n.a. & n.a. & n.a. \\
\hline Rate of growth of loans & 10.12* & 7.19 & 7.83 & 5.22 & $35.59 *$ & 26.47 & 20.26 & 16.39 & $18.82 * *$ & 18.54 & 11.91 & 15.07 \\
\hline Interbank debt ratio ${ }^{\mathrm{e}}$ & $13.14 * *$ & 14.77 & $11.44 * * *$ & 13.52 & 5.36 & 5.42 & 2.57 & 2.12 & n.a. & n.a. & n.a. & n.a. \\
\hline
\end{tabular}

a. Indicators are defined as in table 1 .

b. The statistical tests are the t-test for the difference in means of the two groups and the Mann-Whitney test for the difference in medians of the two groups.

c. Mexico: Risk-weighted-capital-to-total-asset ratio; Venezuela: Capital-to-total-asset ratio; Colombia: Equity-to-assets.

d. Mexico and Venezuela: Interest rate on deposits. Colombia: Interest rate on loans.

e. Ratio of Interbank debt to total loans.

*** significant at the 1 percent level; **significant at the 5 percent level; * significant at the 10 percent level.

n.a. $=$ not available 
Table 3 Assessing the quality of traditional and alternative indicators in Mexico (1993-95), Venezuela (1993-94) and Colombia (1981-88) ${ }^{\mathrm{a}}$

\begin{tabular}{|c|c|c|c|c|c|c|}
\hline \multirow{3}{*}{$\begin{array}{l}\text { Countries } \\
\text { Traditional indicators }\end{array}$} & \multicolumn{2}{|l|}{ MEXICO } & \multicolumn{2}{|c|}{ VENEZUELA } & \multicolumn{2}{|l|}{ COLOMBIA } \\
\hline & $\begin{array}{l}\text { Accuracy in } \\
\text { predicting bank } \\
\text { problems }(\%)^{\mathbf{b}}\end{array}$ & $\begin{array}{l}\text { Ratio of good } \\
\text { to bad signals }\end{array}$ & $\begin{array}{l}\text { Accuracy in } \\
\text { predicting bank } \\
\text { problems }(\%)^{\mathbf{b}}\end{array}$ & $\begin{array}{l}\text { Ratio of good } \\
\text { to bad signals }\end{array}$ & $\begin{array}{l}\text { Accuracy in } \\
\text { predicting bank } \\
\text { problems }(\%)^{\mathbf{b}}\end{array}$ & $\begin{array}{l}\text { Ratio of good } \\
\text { to bad signals }\end{array}$ \\
\hline & & & & & & \\
\hline Capitalization & 7 & 0.35 & 31 & 1.13 & 14 & 0.52 \\
\hline Change in equity prices & 37 & 0.5 & n.a. & n.a. & 25 & 0.50 \\
\hline Net profits to income & 60 & 0.88 & 13 & 1.56 & 43 & 3.55 \\
\hline Operating costs to assets & 40 & 0.63 & 13 & 1.13 & 29 & 0.79 \\
\hline Liquidity ratio & 7 & 0.36 & 13 & 1.00 & 29 & 1.00 \\
\hline Alternative indicators & & & & & & \\
\hline Interest rate on deposits & 80 & 2.13 & 69 & 2.57 & 71 & 1.00 \\
\hline Bank spread & 73 & 3.52 & 62 & 0.79 & n.a. & n.a. \\
\hline Rate of growth of loans & 58 & 1.38 & 19 & 0.89 & 57 & 0.79 \\
\hline Interbank debt growth & 80 & 2.85 & 56 & 0.49 & n.a. & n.a \\
\hline
\end{tabular}

a. Indicators are defined as in table 1 .

b. Episodes of bank problems accurately signaled in advance by the indicator, as a percentage of all such episodes

c. Number of banks for which indicators provided "good" signals to number of banks for which indicators provided "bad" signals. This ratio includes all banks in the sample (banks in crisis and noncrisis banks).

n.a. = not available 
Table 4 Means and medians of traditional and alternative early warning indicators in Thailand, Korea, and Malaysia (1995-97) ${ }^{\text {a, b }}$

\begin{tabular}{|c|c|c|c|c|c|c|c|c|c|c|c|c|}
\hline Countries & \multicolumn{4}{|c|}{ THAILAND } & \multicolumn{4}{|c|}{ KOREA } & \multicolumn{4}{|c|}{ MALAYSIA } \\
\hline & \multicolumn{2}{|c|}{ Means } & \multicolumn{2}{|c|}{ Medians } & \multicolumn{2}{|c|}{ Means } & \multicolumn{2}{|c|}{ Medians } & \multicolumn{2}{|c|}{ Means } & \multicolumn{2}{|c|}{ Medians } \\
\hline & $\begin{array}{l}\text { Banks in } \\
\text { crisis }\end{array}$ & $\begin{array}{l}\text { Noncrisis } \\
\text { banks }\end{array}$ & $\begin{array}{l}\text { Banks in } \\
\text { crisis }\end{array}$ & $\begin{array}{l}\text { Noncrisis } \\
\text { banks }\end{array}$ & $\begin{array}{l}\text { Banks in } \\
\text { crisis }\end{array}$ & $\begin{array}{l}\text { Noncrisis } \\
\text { banks }\end{array}$ & $\begin{array}{l}\text { Banks in } \\
\text { crisis }\end{array}$ & $\begin{array}{l}\text { Noncrisis } \\
\text { banks }\end{array}$ & $\begin{array}{l}\text { Banks in } \\
\text { crisis }\end{array}$ & $\begin{array}{l}\text { Noncrisis } \\
\text { banks }\end{array}$ & $\begin{array}{l}\text { Banks in } \\
\text { crisis }\end{array}$ & $\begin{array}{l}\text { Noncrisis } \\
\text { banks }\end{array}$ \\
\hline Traditional indicators & & & & & & & & & & & & \\
\hline Capitalization $^{\mathrm{c}}$ & 8.06 & 7.57 & 7.83 & 7.3 & 7.93 & 8.32 & 7.29 & 8.21 & $7.38 * *$ & 9.03 & $7.02 * *$ & 8.37 \\
\hline Net profits to income & 9.66 & 13.77 & $7.89 *$ & 13.3 & $3.15 * *$ & 6.08 & $3.43 * * *$ & 5.90 & 11.30 & 12.56 & 13.96 & 14.08 \\
\hline Operating costs to assets & 2.41 & 2.42 & 2.52 & 2.35 & $2.97 * *$ & 3.54 & $3.16 * *$ & 3.38 & 2.08 & 2.23 & 1.96 & 1.95 \\
\hline Liquidity ratio & 9.6 & 9.5 & 9.2 & 9.16 & $18.39 * *$ & 21.41 & 18.44 & 20.73 & $18.30 * *$ & 23.90 & $16.22 * *$ & 23.43 \\
\hline Alternative indicators & & & & & & & & & & & & \\
\hline Interest rate on deposits & $8.95 * *$ & 7.64 & $8.75 * *$ & 8.02 & $8.12 *$ & 6.29 & 5.83 & 6.0 & 4.16 & 4.43 & 4.07 & 4.00 \\
\hline Bank spread & $2.80 * *$ & 3.87 & $2.68 * *$ & 3.95 & $5.12 * *$ & 7.85 & $5.30 * *$ & 7.47 & $6.17 * *$ & 7.21 & $5.90 *$ & 6.78 \\
\hline Rate of growth of loans & 20.61 & 20.57 & 20.97 & 20.32 & 21.41 & 21.74 & 20.28 & 21.35 & 41.24 & 48.34 & 22.74 & 33.34 \\
\hline
\end{tabular}

a. Indicators are defined as in table 1.

b. The statistical tests are the t-test for the difference in means of the two groups of banks and the Mann-Whitney test for the difference in medians

of the two groups.

c. Equity-to-assets

*** significant at the 1 percent level; **significant at the 5 percent level; * significant at the 10 percent level. 
Table 5 Assessing the quality of traditional and alternative indicators in Thailand, Korea, and Malaysia ${ }^{\mathrm{a}}$

\begin{tabular}{|c|c|c|c|c|c|c|}
\hline \multirow{3}{*}{$\begin{array}{l}\text { Countries } \\
\\
\text { Traditional indicators }\end{array}$} & \multicolumn{2}{|c|}{ THAILAND } & \multicolumn{2}{|l|}{ KOREA } & \multicolumn{2}{|l|}{ MALAYSIA } \\
\hline & $\begin{array}{l}\text { Accuracy in } \\
\text { predicting bank } \\
\text { problems }(\%)^{\mathbf{b}}\end{array}$ & $\begin{array}{l}\text { Ratio of good } \\
\text { to bad signals }\end{array}$ & $\begin{array}{l}\text { Accuracy in } \\
\text { predicting bank } \\
\text { problems }(\%)^{\mathbf{b}}\end{array}$ & $\begin{array}{l}\text { Ratio of good } \\
\text { To bad signals }\end{array}$ & $\begin{array}{l}\text { Accuracy in } \\
\text { predicting bank } \\
\text { problems }(\%)^{\mathbf{b}}\end{array}$ & $\begin{array}{l}\text { Ratio of good } \\
\text { to bad signals }\end{array}$ \\
\hline & & & & & & \\
\hline Capitalization & 30 & 0.66 & Meaningless (100) & Always gave & 37 & 0.9 \\
\hline Net profits to income & 60 & 0.75 & 60 & 1.7 & 50 & 0.9 \\
\hline Operating costs to assets & 20 & 1.0 & 20 & 0.78 & 25 & 0.75 \\
\hline Liquidity ratio & 50 & 0.60 & 56 & 1.8 & 60 & 0.5 \\
\hline Alternative indicators & & & & & & \\
\hline Interest rate on deposits & 66 & 3.66 & 80 & 1.5 & 62 & 1.3 \\
\hline Bank spread & 83 & 1.14 & 93 & 3.3 & 88 & 1.1 \\
\hline Rate of growth of loans & 50 & 1.14 & 60 & 1.9 & 40 & 1.44 \\
\hline
\end{tabular}

a. Indicators are defined as in table 1 .

b. Episodes of bank problems accurately signaled in advance by the indicator, as a percentage of all such episodes.

c. Number of banks for which indicators provided "good" signals to number of banks for which indicators provided "bad" signals. This ratio includes all banks in the sample (banks in crisis and noncrisis banks). 


\section{REFERENCES}

Benston, George J. 1985. "An Analysis of the Causes of Savings and Loan Association Failures." Monograph Series in Finance and Economics, New York University.

Barth, James R., R. Dan Brumbaugh Jr., Daniel Sauerhaft, and George H.K. Wang. 1985. “Thrift Institution Failures: Causes and Policy Issues", in Bank Structure and Competition, Conference Proceedings, Federal Reserve Bank of Chicago, 380-95.

Benston, George J. 1985. “An Analysis of the Causes of Savings and Loan Association Failures”, Monograph Series in Finance and Economics. New York University.

Basel Committee on Banking Supervision, 2000. "The New Basel Capital Accord”, Consultative Document (January). Bank for International Settlements, Basel, Switzerland.

Bongini, Paola, Stijn Claessens and Giovanni Ferri. 1999. “ The Political Economy of Distress in East Asian Financial Institutions”, photocopy. World Bank, Washington, DC.

Calomiris, Charles. 1999. Building an Incentive-Compatible Safety Net, Journal of Banking and Finance, vol. 23: 1499-1519.

Caprio, Gerard, J. and Klingebiel, Daniela. 1996. Bank Insolvency: Bad Luck, Bad Policy, or Bad Banking? Paper prepared for the World Bank's Annual Bank Conference on Development Economics. World Bank, Washington, DC, April 25-26.

Demirguc-Kunt, Asli and Enrica Detragiache. 2000. "Monitoring Banking Sector Fragility: A Multivariate Logit Approach”, World Bank Economic Review. World Bank, Washington, DC.

Demirguc-Kunt, Asli. 1989. "Deposit-Institution Failures: A Review of Empirical Literature", Federal Reserve Bank of Cleveland, Economic Review, Fourth Quarter, 2-18.

Fitch IBCA. 2000. "Everything you wanted to know about Fitch IBCA and the BIS/Basle/ rules but were too afraid/too baffle to ask", March.

Fitch IBCA. 1998. "Bank Rating Methodology”, April.

Flannery, Mark J., and Sorin M. Sorescu. 1996. "Evidence of Bank Market Discipline in Subordinated Debenture Yields:1983-1991.” The Journal of Finance, 51 (4): 1347-77 (September).

Goldstein, M., G. Kaminsky and C. Reinhart. 2000. Assessing Financial Vulnerability: An Early Warning System for Emerging Markets, Institute for International Economics, Washington, DC. 
Gonzalez-Hermosillo, Brenda, Pazarbasioglu Ceyla, and Billings Robert. 1996. "Banking System Fragility: Likelihood Versus Timing of Failure--An Application to the Mexican Financial Crisis.” IMF Working Paper WP/96/12, December. International Monetary Fund, Washington, DC.

Honohan, Patrick and Daniela Klingebiel. 2000. Controlling Fiscal Costs of Banking Crises. World Bank, Washington, DC (May).

Honohan, Patrick. 1997. "Banking System Failures in Developing and Transition Countries: Diagnosis and Prediction”, BIS Working Papers no. 39 (January). Bank for International Settlements, Basel, Switzerland.

Kaminsky, Graciela, and Reinhart, Carmen. 1999. "The Twin Crises: The Causes of Banking and Balance of Payments Problems.” American Economic Review, 89, (3): 473-500.

Lane, William R., Stephen W. Looney and James W. Wansley. 1996. “An Application of the Cox Proportional Hazards Model to Bank Failure", Journal of Banking and Finance, 10: 511-31.

Lindgren, Carl-Johan, Tomas Balino, Charles Enoch, Anne-Marie Gulde, Marc Quintyn, and Leslie Teo. 1999. Financial Sector Crisis and Restructuring: Lessons from Asia, Occasional Paper 188. Washington, DC: International Monetary Fund.

Lindgren, Carl-Johan, Gillian Garcia, and Matthew I. Saal. 1996. Bank Soundness and Macroeconomic Policy. Washington, DC: International Monetary Fund.

Marcus, A.J., "Deregulation and Bank Financial Policy". 1984. Journal of Banking and Finance, 8: 557-65.

Martin, Daniel. 1997. "Early Warning of Bank Failure.” Journal of Banking and Finance, 1: 249-76 (November).

Moody’s Investors Service. 1999. "Rating Methodology: Bank Credit Risk in Emerging Markets" (July).

Moody’s Investors Service. 1999. Moody's Research Guide for Latin American Bank Financial Statements" (March).

Moody’s Investors Service. 1997. “Moody's Approach to Analyzing and Rating Emerging Market Banking Systems: Argentina as a Case Study" (July). 
Pettway, Richard H., and Sinkey, John F. 1980. Establishing On-Site Bank Examination Priorities: An Early Warning System Using Accounting and Market Information, Journal of Finance, 35, (1): 137-50 (March).

Rojas-Suárez, Liliana, and Steven Weisbrod. 1996. "Banking Crises in Latin America: Experiences and Issues" in Banking Crises in Latin America, Ricardo Hausmann and Liliana Rojas-Suárez, eds. Inter-American Development Bank.

Rojas-Suárez, Liliana, and Steven Weisbrod. 1997. Toward an Effective Financial Regulatory and Supervisory Framework for Latin America: Dealing with the Transition, in Safe and Sound Financial Systems: What Works for Latin America, Liliana Rojas-Suarez, ed. InterAmerican Development Bank.

Rojas-Suárez, Liliana, and Steven Weisbrod. 1995. Financial Fragilities in Latin America: the 1980s and the 1990s, IMF Occasional Paper no. 132, Washington, DC: International Monetary Fund.

Shick, Richard A., and Sherman, Lawrence F. 1980. Bank Stock Prices as an Early Warning System for Changes in Condition, Journal of Bank Research, 11: 136-46 (Autumn).

Sharpe, William F. 1978. Bank Capital Adequacy, Deposit Insurance and Security Values, Journal of Financial and Qualitative Analysis, Proceedings, issue 13: 701-18.

Sinkey, Joseph. 1975. A Multivariate Statistical Analysis of the Characteristics of Problem Banks, Journal of Finance 30: 21-36 (March).

Sinkey, Joseph. 1979. Problem and failed institutions in the commercial banking industry, Contemporary Studies in Economic and Financial Analysis, vol. 4, JAI Press.

Whalen, Gary and James Thomson. 1988. Using Financial Data to Identify Changes in Bank Condition, Economic Review, Federal Reserve Bank of Cleveland, Quarter 2: 17-26. 